\title{
Semi-natural Grassland Vegetation Database of Latvia
}

\author{
Solvita Rūsiṇa
}

\begin{abstract}
The Semi-natural Grassland Vegetation Database of Latvia (GIVD ID EU-LV-001) was first developed in 1999 as part of the $\mathrm{PhD}$ Thesis on syntaxonomy and diversity of dry and mesic grasslands of Latvia. The database includes the original relevés established by the author as early as 1997. The majority of relevés belongs to the Filipendulo-Helictotrichion (Festuco-Brometea) and Arrhenatheretalia communities, but Molinietalia, Nardetalia, Caricion nigrae, Koelerion glaucae and Plantagini-Festucion are covered, as well. The total number of relevés stored is 2,500 and there are approximately 700 relevés to be digitised. Plot size varies from 1 to $125 \mathrm{~m}^{2}$, the majority of relevés are $4-9 \mathrm{~m}^{2}$ large. Relevés contain records of vascular plants, bryophytes, and lichens (excl. non-terrestrial taxa) percentage cover values. The database holds information on geographic localisation, slope inclination and aspect, management type, soil type etc. Part of the relevés are included in the large-scale database: Dry Grasslands in the Baltic and Nordic Region. Several publications are based on the database dealing with Latvia's vegetation classification at regional and local scale and with long-term changes of vegetation. The Laboratory of Geobotany at the Institute of Biology of the University of Latvia is planning to develop a joint database of vegetation of Latvia and the current database will be a part of that database.
\end{abstract}

Keywords: Eastern Baltics; meadow; pasture; relevé.

GIVD Database ID: EU-LV-001

Last update: 2012-05-02

\section{Semi-natural Grassland Vegetation Database of Latvia}

Scope: The aim of the database was to contribute to the development of semi-natural grassland syntaxonomy of Latvia. The only sources are original relevés established by S.Rusina (Molinio-Arrhenatheretea, Calluno-Ulicetea, Festuco-Brometea, Trifolio-Geranietea, Magnocaricion, Caricion nigrae). Other possible sources to be included are no more than 10 publications with approx. 30-60 relevés.

Status: ongoing capture Period: 1997-2011

Database manager(s): Solvita Rusina (rusina@lu.lv)

Owner: Solvita Rusina (private)

Web address: [NA]

Availability: according to a specific agreement

Database format(s): TURBOVEG

Publication: [NA]

Plot type(s): normal plots; time series

Non-overlapping plots: 2,165

Total plot observations: 2,500

Countries: LV: $100.0 \%$

Forest: $0 \%$ - Non-forest: aquatic: $0 \%$; semi-aquatic: $0 \%$; arctic-alpine: $0 \%$; natural: $0 \%$; semi-natural: $100 \%$; anthropogenic: $0 \%$

Guilds: all vascular plants: $100 \%$; bryophytes (terricolous or aquatic): $80 \%$; lichens (terricolous or aquatic): $80 \%$

Environmental data: slope aspect: $90 \%$; slope inclination: $90 \%$; soil depth: $100 \%$; surface cover other than plants (open soil, litter, bare rock etc.): $10 \%$; soil pH: $10 \%$; other soil attributes: $90 \%$

Performance measure(s): cover: $100 \%$

Geographic localisation: GPS coordinates (precision $25 \mathrm{~m}$ or less): $100 \%$

Sampling periods: $1990-1999: 35.0 \%$; 2000-2009: $65.0 \%$

Information as of 2012-07-12; further details and future updates available from http://www.givd.info/ID/EU-LV-001

Solvita Rūsiņa (rusina@lu.lv)

Department of Physical Geography, Faculty of Geography and Earth Sciences, University of Latvia, Alberta 10, LV 1010 Riga, LATVIA 